\title{
Characteristics of Women Who Have Had Cosmetic Breast Implants That Could Be Associated with Increased Suicide Risk: A Systematic Review, Proposing a Suicide Prevention Model
}

\author{
Nikolaos Manoloudakis ${ }^{1,2}$, Georgios Labiris ${ }^{1}$, Nefeli Karakitsou ${ }^{3}$, Jong B Kim², Yezen Sheena ${ }^{2}$, \\ Dimitrios Niakas ${ }^{1}$ \\ ${ }^{1}$ Faculty of Social Sciences, Hellenic Open University, Cambridge; ${ }^{2}$ Plastic and Reconstructive Surgery Department, East and North \\ Hertfordshire NHS Trust, Lister Hospital, Stevenage; ${ }^{3}$ Cambridge and Peterborough NHS foundation Trust, Fulbourn Psychiatric Hospital, \\ Cambridge, UK
}

Literature indicates an increased risk of suicide among women who have had cosmetic breast implants. An explanatory model for this association has not been established. Some studies conclude that women with cosmetic breast implants demonstrate some characteristics that are associated with increased suicide risk while others support that the breast augmentation protects from suicide. A systematic review including data collection from January 1961 up to February 2014 was conducted. The results were incorporated to pre-existing suicide risk models of the general population. A modified suicide risk model was created for the female cosmetic augmentation mammaplasty candidate. A 2-3 times increased suicide risk among women that undergo cosmetic breast augmentation has been identified. Breast augmentation patients show some characteristics that are associated with increased suicide risk. The majority of women reported high postoperative satisfaction. Recent research indicates that the Autoimmune syndrome induced by adjuvants and fibromyalgia syndrome are associated with silicone implantation. A thorough surgical, medical and psycho-social (psychiatric, family, reproductive, and occupational) history should be included in the preoperative assessment of women seeking to undergo cosmetic breast augmentation. Breast augmentation surgery can stimulate a systematic stress response and increase the risk of suicide. Each risk factor of suicide has poor predictive value when considered independently and can result in prediction errors. A clinical management model has been proposed considering the overlapping risk factors of women that undergo cosmetic breast augmentation with suicide.

Keywords Cosmetic surgery / Silicone / Breast implants / Mammaplasty / Suicide
Correspondence:

Nikolaos Manoloudakis

Plastic and Reconstructive Surgery

Department, Faculty of Social

Sciences, Hellenic Open University,

Coreys Mill Lane, Stevenage,

Hertfordshire, SG1 4AB, UK

Tel: +44-74-4236-4832

Fax: +44-12-3479-2223

E-mail:nikolaos.manoloudakis@nhs.net

Received: 26 Jun 2014 • Revised: 21 Jul 2014 • Accepted: 26 Jul 2014

pISSN: 2234-6163 • elSSN: 2234-6171 • http://dx.doi.org/10.5999/aps.2015.42.2.131 • Arch Plast Surg 2015;42:131-142

No potential conflict of interest relevant to this article was reported.

\section{INTRODUCTION}

According to the National Institute of Mental Health in the US, suicide is a major, preventable public health problem as the tenth leading cause of death, accounting for 34,598 deaths per annum $[1,2]$. With an overall rate of 11.3 suicide deaths per 100,000

Copyright $\odot 2015$ The Korean Society of Plastic and Reconstructive Surgeons

This is an Open Access article distributed under the terms of the Creative Commons Attribution Non-Commercial License (http://creativecommons.org/

licenses/by-nc/3.0/) which permits unrestricted non-commercial use, distribution, and reproduction in any medium, provided the original work is properly cited.

www.e-aps.org 
people and an estimated 11 attempted suicides per actual suicide death $[1,2]$. Recent research indicates an increased risk of suicide among women who have had cosmetic breast implants [3-9]. This unanticipated finding has caused a conflict regarding the safety of cosmetic breast augmentation and has led to several empirical explanations $[10,11]$.

Among them the specific characteristics of women who have had cosmetic breast implants and their association with raised suicide risk has been encountered as a reasonable explanation while others support that the breast augmentation confer protection from suicide [10-15]. McLaughlin et al. [12] recommended further epidemiological studies in order to identify whether or not there is a causal relationship between breast implantation and suicide and large-scale retrospective cohort studies to compare the suicide risk in women with and without implants. Joiner [13] estimated that the suicide risk in women with cosmetic breast augmentation should be four times greater than the general population's rate and concluded that the cosmetic augmentation operation may suppress suicidality.

The current challenge is to demonstrate an explanatory model and identify specific predisposing suicide risk factors in those women. The aim of this article is to review the literature regarding the characteristics of women who have had cosmetic breast implants that could be associated with increased suicide risk and to attempt to devise a conceptualized suicide risk model for the women candidates of cosmetic breast augmentation. Before discussing that it is necessary to review the studies that investigate the association between cosmetic breast augmentation and suicide risk.

\section{METHODS}

A systematic review [16-20] was conducted investigating the association between cosmetic breast augmentation and suicide risk and the characteristics of the breast augmentation female patient and their relation with suicide. Our data collection period was from January 1961 until February 2014. The review included prospect cohort studies, retrospective cohort studies, randomized clinical trials, case-control studies clinical trials and excluded systematic reviews.

Our review grouped the identified studies in 3 different categories based on their investigation subject: 1) Epidemiological studies that were investigating the relationship between cosmetic breast augmentation and suicide in women; 2) Studies that evaluated the psychosocial and psychological status both before and after breast augmentation procedures were grouped together; 3 ) Epidemiological studies that were focusing on psychiatric history, demographic characteristics, life-style characteristics and reproductive history of women with cosmetic breast implants.

We excluded studies that evaluated the usage of breast implants for reconstructive purposes, studies that evaluated general cosmetic surgery rather than cosmetic breast augmentation and studies that included breast augmentation in men. Database was collected from: PubMed, MEDLINE, CINAHL, PsycINFO, Web of Science, OvidSP, ScienceDirect, JAMA Psychiatry, with the keywords: Cosmetic surgery, Suicide and/or predictor factors, Silicone breast implants/breast augmentation and/or self-esteem, Body image, Psychosocial outcomes. Further studies were yielded from the reference lists used in the identified articles. After exporting the data, we evaluated them based on the scientific question and exclusion criteria. Evaluation of each result separately was followed and studies were organized according to the degree of similarity among them and reference tables were created. The results were incorporated to pre-existing suicide risk models of the general population and a modified suicide risk model was created for the female cosmetic augmentation mammaplasty candidate.

\section{RESULTS}

Our literature search identified 7 epidemiological cohort studies addressing the issue of cosmetic breast augmentation and suicide, which are presented in chronological order in Table 1 [3-9].

This demonstrates available data such as the follow up period, the age and the outcome after cosmetic breast augmentation. Among these studies, only Villeneuve et al. [8] didn't find any relationship between cosmetic breast augmentation and high risk of suicide. The other studies found a two to three fold increased risk of suicide in women with cosmetic augmentation implants compared to the general population. Three of the studies [7-9], suggest that the rate of suicide is higher in women who underwent breast augmentation after the age of 40 and for women who had their implants for longer period of time ( $>$ than 10 years). Several proposed explanations for this association include the higher prevalence of psychopathology [4], mental illness history that required hospital treatment [6] and significant underlying psychiatric morbidity in the above groups [9]. The non prospective study design with regards to the association between suicide and cosmetic breast implants limits any definitive conclusions on causality in this relationship [15].

The impact of patients postoperative expectations and the level of postoperative satisfaction, have been associated with poor psychosocial outcomes that could potentially relate with the increased rate of suicides among cosmetic breast augmentation patients $[21,22]$. Ten studies focusing on the psychosocial outcomes (self-esteem, body-image, postoperative satisfaction, qual- 
Table 1. Suicide in women with cosmetic breast implants

\begin{tabular}{|c|c|c|c|c|c|}
\hline Author(s) study & Study objective & Outcome & Age (yr) & $\begin{array}{l}\text { Follow-up } \\
\text { period (yr) }\end{array}$ & $\begin{array}{c}\text { Suggestions/associated } \\
\text { factors and/or possible } \\
\text { explanations given }\end{array}$ \\
\hline $\begin{array}{l}\text { Brinton et al. [3], 2001, } \\
\text { Retrospective cohort study }\end{array}$ & $\begin{array}{l}\text { Mortality among augmentation } \\
\text { mammaplasty patients }\end{array}$ & $\begin{array}{l}\text { 2-3 times higher suicide rate } \\
(\mathrm{SMR}=1.54 ; 95 \% \mathrm{Cl}, 1.0-2.4) .\end{array}$ & 34 (mean) & 13 & $\begin{array}{l}\text { Mood disorders, low self- } \\
\text { esteem marital difficulties } \\
\text { older age at implantation }\end{array}$ \\
\hline $\begin{array}{l}\text { Koot et al. [4], 2003, } \\
\text { Prospective study }\end{array}$ & $\begin{array}{l}\text { Mortality among Swedish women with } \\
\text { cosmetic breast implants }\end{array}$ & $\begin{array}{l}\text { Increased risk of suicide (SMR=2.9; } \\
95 \% \mathrm{Cl}, 1.6-4.8)\end{array}$ & 31.6 (mean) & 28 & $\begin{array}{l}\text { Greater prevalence of } \\
\text { psychopathology }\end{array}$ \\
\hline $\begin{array}{l}\text { Pukkala et al. [5], 2003, } \\
\text { Cohort study }\end{array}$ & $\begin{array}{l}\text { Causes of death among Finnish women } \\
\text { with cosmetic breast implants }\end{array}$ & $\begin{array}{l}\text { 3, 2-fold increase risk from suicide } \\
\text { (SMR=3.19; } 95 \% \mathrm{Cl}, 1.5-5.9)\end{array}$ & $<30,47 \%$ & $\begin{array}{l}30 \text { Mean } \\
\text { length, } 10.3\end{array}$ & $\begin{array}{l}\text { Underlying psychopathology. } \\
\text { Further investigation required }\end{array}$ \\
\hline $\begin{array}{l}\text { Jacobsen et al. [6], 2004, } \\
\text { Cohort study }\end{array}$ & $\begin{array}{l}\text { Mortality and suicide among Danish } \\
\text { women with cosmetic breast implants }\end{array}$ & $\begin{array}{l}\text { 2-3 fold increased risks of suicide } \\
\text { (SMR }=3.1 ; 95 \% \mathrm{Cl}, 1.7-5.2)\end{array}$ & 31 (mean) & 22 & $\begin{array}{l}\text { Mental illness history requiring } \\
\text { hospital admission }\end{array}$ \\
\hline $\begin{array}{l}\text { Brinton et al. [7], 2006, } \\
\text { Retrospective cohort study }\end{array}$ & $\begin{array}{l}\text { Mortality rates among augmentation } \\
\text { Mammaplasty patients an update }\end{array}$ & $\begin{array}{l}\text { Excess risk of suicide. } \\
\text { Risk of suicide increased after the } \\
\text { first postoperative decade } \\
\text { (SMR=1.63; 95\% Cl, 1.1-2.3). }\end{array}$ & 34 (mean) & $\begin{array}{l}\text { Followed their } \\
\text { initial cohort } \\
\text { for additional } 5\end{array}$ & $\begin{array}{l}\text { Reasons remain unclear } \\
\text { predisposing personality } \\
\text { characteristics, low self- } \\
\text { esteem, anxiety, depression }\end{array}$ \\
\hline $\begin{array}{l}\text { Villeneuve et al. [8], 2006, } \\
\text { Cohort study }\end{array}$ & $\begin{array}{l}\text { Mortality among Canadian women with } \\
\text { cosmetic breast implants }\end{array}$ & $\begin{array}{l}\text { No differences in suicide rates } \\
\text { between implant patients and other } \\
\text { cosmetic plastic surgery patients. } \\
\text { Higher standardized mortality ratios } \\
\text { for suicide for women who received } \\
\text { breast implants } \geq 40 \text { years and for } \\
\text { those who had for longer period } \\
\text { their implants. }\end{array}$ & 32 (mean) & 15 & $\begin{array}{l}\text { Further studies are needed to } \\
\text { evaluate detailed risk factors } \\
\text { between suicides and breast } \\
\text { implant patients }\end{array}$ \\
\hline $\begin{array}{l}\text { Lipworth et al. [9], 2007, } \\
\text { Cohort study }\end{array}$ & $\begin{array}{l}\text { Excess mortality from suicide and } \\
\text { other external causes of death among } \\
\text { women with cosmetic breast implants }\end{array}$ & $\begin{array}{l}3 \text { fold excess risk of suicide } \\
\text { (SMR=3; } 95 \% \mathrm{Cl}, 1.9-4.5) \text {. } \\
\text { The increased risk of suicide was not } \\
\text { apparent until } 10 \text { years after } \\
\text { implantation. }\end{array}$ & 32 (mean) & 18.7 & $\begin{array}{l}\text { Significant underlying } \\
\text { psychiatric morbidity rather } \\
\text { than a causal association with } \\
\text { silicone implants }\end{array}$ \\
\hline
\end{tabular}

ity of life) of women with breast augmentation were included for our current review (Table 2) [23-32].

In summary the majority of women reported high postoperative satisfaction and some of them would have surgery again [21]. Beale et al. [26] using the Rosenberg Self-esteem Scale and the Cesarec-Mark personality Schedule for a 12 months follow up period tried to assess the predictors of successful outcome from augmentation mammaplasty and concluded that $78 \%$ of women were completely satisfied. They also resulted that patients with unrealistic expectations and psychiatric problems are more likely to be related with poor outcome such as low self-esteem [26]. Kilman et al. [27] concluded that breast mammaplasty enhances body image and increases sexual interest of the patient's partner. Meyer and Ringberg [28], assessed the personality, the psychosocial and psychiatric characteristics of those women and concluded that $86 \%$ were satisfied and that their social and psychological expectations had been fulfilled [28]. Young et al. [29] reported postoperative increased self confidence among $88 \%$ of the women and $95 \%$ postoperative rates of satisfaction. Cash et al. [31] found that more than $90 \%$ of women were satisfied with the outcome and attained expectations of enhanced body image. The above studies demonstrate that the postoperative outcome is unlikely to contribute to the increased suicide risk among those women.

The specific characteristics of women that undergo cosmetic breast augmentation have been assumed to be linked with the increased suicide risk of this population [15,21]. Several researchers have conducted studies in order to identify characteristics (demographic, lifestyle, psychiatric and reproductive history) of women with cosmetic breast implants. 10 studies were identified as demonstrated in Table 3 in chronological order [22,26, 33-40].

Most studies agree that the typical breast augmentation female patient [34-39] is more often, Caucasian, between 28 to 44 years of age, thin and tall, smoker, consuming alcohol, with good education backgrounds $[33-35,37,40]$ and likely to have history of depression, anxiety and neurotic personality. They seek for psychiatric consultations more often than the general population and have increased rate of psychiatric hospital admissions prior to the cosmetic surgery [22,26,37-40]. Regarding their reproductive history they have younger age at menopause, greater number of full pregnancies and are more likely to have had an induced abortion $[34,36,37]$. Studies remain inconclusive regarding their marital status $[26,33,35,40]$. 


\begin{tabular}{|c|c|c|c|c|c|c|}
\hline Author(s), study & Study objective & Scales used & $\begin{array}{l}\text { Age } \\
(y r)\end{array}$ & $\begin{array}{l}\text { Follow- } \\
\text { up } \\
\text { period }\end{array}$ & $\begin{array}{l}\text { Associated factors } \\
\text { with poor } \\
\text { outcomes }\end{array}$ & Outcome \\
\hline $\begin{array}{l}\text { Edgerton et al. [23], } \\
\text { (1961) } \\
\text { Presurgical and } \\
\text { postsurgical interviews } \\
\text { and psychological } \\
\text { tests }\end{array}$ & $\begin{array}{l}\text { Augmentation mammaplasty. } \\
\text { Further surgical and psychiatric } \\
\text { evaluation }\end{array}$ & $\begin{array}{l}\text { Guilford-Zimmerman } \\
\text { Temperament Survey } \\
\text { Morale-Loss Scale } \\
\text { Tennesse Dept of Health Self- } \\
\text { Concept Scale } \\
\text { Sentence Completion Test }\end{array}$ & $17-52$ & $\begin{array}{c}6 \text { mo to } \\
3 \mathrm{yr}\end{array}$ & $\begin{array}{l}\text { Depression } \\
\text { Unrealistic expectations } \\
\text { Marital difficulties } \\
\text { Patients asking for } \\
\text { operation urgently }\end{array}$ & $\begin{array}{l}\text { Enhanced self-esteem } \\
\text { Patients generally satisfied } \\
\text { with outcome }\end{array}$ \\
\hline $\begin{array}{l}\text { Shipley et al. [24], } \\
\text { (1978) } \\
\text { Presurgical interview } \\
\text { and postsurgical mail } \\
\text { survey }\end{array}$ & $\begin{array}{l}\text { Psychosocial effects of cosmetic } \\
\text { augmentation mammaplasty }\end{array}$ & $\begin{array}{l}\text { California Psychological Inventory } \\
\text { Ziller Social Self Esteem Test } \\
\text { Dress Popularity and Activity } \\
\text { Questionnaire }\end{array}$ & $\begin{array}{c}30.5 \\
\text { (mean) }\end{array}$ & $3 \mathrm{mo}$ & Not stated & $\begin{array}{l}\text { The augmented women } \\
\text { showed improved body } \\
\text { image }\end{array}$ \\
\hline $\begin{array}{l}\text { Sihm et al. [25], (1978) } \\
\text { Presurgical and } \\
\text { postsurgical } \\
\text { psychological and } \\
\text { psychiatric } \\
\text { examination }\end{array}$ & $\begin{array}{l}\text { Psychological assessment before } \\
\text { and after augmentation } \\
\text { mammaplasty }\end{array}$ & $\begin{array}{l}\text { Activity Questionnaire } \\
\text { Unspecified measures of body } \\
\text { image, identity, intellectual level, } \\
\text { personality } \\
\text { Integration }\end{array}$ & $21-45$ & $12 \mathrm{mo}$ & Not stated & $\begin{array}{l}\text { Improvement of self } \\
\text { confidence }\end{array}$ \\
\hline $\begin{array}{l}\text { Beale et al. [26], (1985) } \\
\text { Subsample followed } \\
\text { longitudinally }\end{array}$ & $\begin{array}{l}\text { Identify predictors of successful } \\
\text { outcome from augmentation } \\
\text { mammaplasty }\end{array}$ & $\begin{array}{l}\text { Rosenberg Self-Esteem scale } \\
\text { Cesarec-Mark Personality } \\
\text { Schedule }\end{array}$ & $\begin{array}{l}\text { Not } \\
\text { stated }\end{array}$ & $12 \mathrm{mo}$ & $\begin{array}{l}\text { Unrealistic expectations } \\
\text { Patients scoring high on } \\
\text { neurotic personality } \\
\text { scale } \\
\text { Goal of surgery is to } \\
\text { improve relationship }\end{array}$ & $78 \%$ completely satisfied \\
\hline $\begin{array}{l}\text { Kilman et al. [27], } \\
\text { (1987) } \\
\text { Retrospective } \\
\text { questionnaire study }\end{array}$ & $\begin{array}{l}\text { Assess impact of augmentation } \\
\text { mammaplasty on personal and } \\
\text { relationship functioning including } \\
\text { sexual life and body image }\end{array}$ & Author's questionnaire & $\begin{array}{c}35 \\
\text { (mean) }\end{array}$ & $\begin{array}{c}3 \text { mo to } \\
3 \mathrm{yr}\end{array}$ & Not stated & $\begin{array}{l}\text { Positive effects on perceived } \\
\text { attractiveness body and } \\
\text { self-image } \\
\text { Partner showing greater } \\
\text { sexual interest due to } \\
\text { perceiving women to be } \\
\text { more attractive }\end{array}$ \\
\hline $\begin{array}{l}\text { Meyer and Ringberg } \\
\text { [28], (1987) } \\
\text { Presurgical and } \\
\text { postsurgical } \\
\text { interviews }\end{array}$ & $\begin{array}{l}\text { Evaluate personality, psychosocial } \\
\text { and psychiatric characteristics of } \\
\text { women that undergo } \\
\text { augmentation mammaplasty }\end{array}$ & $\begin{array}{l}\text { Cesarec-Marke Personality } \\
\text { Scheme } \\
\text { Marke-Nyman test }\end{array}$ & $\begin{array}{c}38.4 \\
\text { (mean) }\end{array}$ & $1 \mathrm{yr}$ & $\begin{array}{l}\text { Specified personality } \\
\text { characteristics }\end{array}$ & $\begin{array}{l}86 \% \text { satisfied with the } \\
\text { results } \\
\text { Social and sexual life } \\
\text { improved }\end{array}$ \\
\hline $\begin{array}{l}\text { Young et al. [29], (1994) } \\
\text { Retrospective telephone } \\
\text { interviews }\end{array}$ & $\begin{array}{l}\text { Evaluate impact of surgery on } \\
\text { psychological parameters } \\
\text { including; body image, self } \\
\text { confidence and interpersonal } \\
\text { functioning }\end{array}$ & Author's questionnaire & $\begin{array}{c}33 \\
\text { (mean) }\end{array}$ & $5 \mathrm{yr}$ & Not stated & $\begin{array}{l}88 \% \text { improved self } \\
\text { confidence } \\
95 \% \text { felt better about } \\
\text { themselves } \\
\text { 86\% operation was a } \\
\text { success } \\
\text { 95\% surgery met their } \\
\text { expectations }\end{array}$ \\
\hline $\begin{array}{l}\text { Rankin et al. [30], } \\
\text { (1998) } \\
\text { Presurgical and } \\
\text { postsurgical } \\
\text { questionnaire }\end{array}$ & $\begin{array}{l}\text { Examine quality of life after } \\
\text { cosmetic surgery including breast } \\
\text { augmentation }\end{array}$ & $\begin{array}{l}\text { Presurgical and postsurgical self- } \\
\text { report questionnaire }\end{array}$ & $\begin{array}{l}31-50 \\
\text { (mean) }\end{array}$ & $1,6 \mathrm{mo}$ & Not stated & Improved quality of life \\
\hline $\begin{array}{l}\text { Cash et al. [31], (2002) } \\
\text { Prospective }\end{array}$ & $\begin{array}{l}\text { To examine the psychosocial } \\
\text { outcomes of breast } \\
\text { augmentation in females with } \\
\text { silicone gel-filled implants }\end{array}$ & $\begin{array}{l}\text { Questionnaire at initial consultation } \\
\text { to evaluate the reasons and } \\
\text { expectations of surgery, as well } \\
\text { as the concerns regarding the } \\
\text { perceived risks }\end{array}$ & $\begin{array}{c}32 \\
\text { (mean) }\end{array}$ & $\begin{array}{l}6,12 \\
24 \mathrm{mo}\end{array}$ & $\begin{array}{l}\text { Postoperative } \\
\text { complications such as } \\
\text { capsular attrition } \\
\text { which compromise the } \\
\text { aesthetically desired } \\
\text { outcome. } \\
\text { Less obvious events did } \\
\text { not did not reduce } \\
\text { satisfaction. }\end{array}$ & $\begin{array}{l}>90 \% \text { were satisfied with } \\
\text { surgery and the } \\
\text { consequent body image } \\
\text { alterations } \\
75 \%-85 \% \text { considered } \\
\text { benefits of surgery } \\
\text { exceeded the risks }\end{array}$ \\
\hline $\begin{array}{l}\text { Sarwer et al. [32], } \\
\text { (2008) } \\
\text { Prospective }\end{array}$ & $\begin{array}{l}\text { To evaluate the patient satisfaction } \\
\text { and psychosocial status } \\
\text { following cosmetic surgery } \\
\text { (including breast augmentation) }\end{array}$ & $\begin{array}{l}\text { Patients completed psychometric } \\
\text { measures of body image, } \\
\text { depressive symptoms and self- } \\
\text { esteem before surgery and at } 3 \text {, } \\
6,12,24 \text { months postoperatively }\end{array}$ & $\begin{array}{l}\text { Not } \\
\text { stated }\end{array}$ & $\begin{array}{c}3,6,12 \\
24 \mathrm{mo}\end{array}$ & Not Stated & $\begin{array}{l}\text { Postoperative satisfaction as } \\
\text { well as self rated } \\
\text { attractiveness at the } 4 \\
\text { postoperative assessment } \\
\text { point. } \\
\text { Two years after surgery 93\% } \\
\text { reported that they would } \\
\text { have surgery again }\end{array}$ \\
\hline
\end{tabular}


Table 3. Other characteristics (demographic/lifestyle/psychiatric/reproductive history)

\begin{tabular}{|c|c|c|c|}
\hline Author(s), study & Study objective & $\begin{array}{l}\text { Mean age at breast } \\
\text { augmentation (yr) }\end{array}$ & Characteristics of women with breast implants \\
\hline $\begin{array}{l}\text { Schlebusch and Levin [22], (1983) } \\
\text { Cohort study }\end{array}$ & $\begin{array}{l}\text { To identify the psychological profile of } \\
\text { women with cosmetic augmentation } \\
\text { mammaplasty }\end{array}$ & Not stated & $\begin{array}{l}\text { - Depression } \\
\cdot \text { Anxiety } \\
\cdot \text { Poor body-image } \\
\cdot \text { Psychosexual problems }\end{array}$ \\
\hline $\begin{array}{l}\text { Beale et al. [26], (1985) } \\
\text { Cohort study }\end{array}$ & $\begin{array}{l}\text { A psychological study attempting to } \\
\text { identify the characteristics of patients } \\
\text { seeking augmentation mammaplasty }\end{array}$ & 28.4 & $\begin{array}{l}\text { - More negative towards their parents } \\
\text { - More strained marital relationship } \\
\text { - More often divorced } \\
\text { - More often visits to psychiatrists } \\
\text { - More neurotic personalities }\end{array}$ \\
\hline $\begin{array}{l}\text { Schlebusch [33], (1989) } \\
\text { Cohort study } \\
\text { Psychological assessment } \\
\text { Interviews }\end{array}$ & $\begin{array}{l}\text { To identify the characteristics of } \\
\text { patients who request augmentation } \\
\text { mammaplasty }\end{array}$ & 30.4 & $\begin{array}{l}\cdot \text { White } \\
\cdot \text { Well-educated } \\
\cdot \text { Married } \\
\cdot \text { Varying degrees of depression }\end{array}$ \\
\hline $\begin{array}{l}\text { Cook et al. [34] (1997) } \\
\text { Case control study } \\
\text { Interview information }\end{array}$ & $\begin{array}{l}\text { To compare selected characteristics of } \\
\text { women with and without breast } \\
\text { augmentation mammaplasty }\end{array}$ & 34 & $\begin{array}{l}\text { - More likely to have had high school education } \\
\text { - Higher household income } \\
\text { - Consumption of alcohol } \\
\text { - More common history of smoking } \\
\text { - Taller and thinner } \\
\text { - Younger age at first pregnancy and full birth } \\
\text { - History of terminated pregnancies } \\
\text { - Use of oral contraceptives for longer period of time } \\
\text { - Greater lifetime number of sexual partners }\end{array}$ \\
\hline $\begin{array}{l}\text { Brinton et al. [35], (2000) } \\
\text { Retrospective cohort study } \\
\text { Questionnaire data }\end{array}$ & $\begin{array}{l}\text { To identify the characteristics of } \\
\text { women with cosmetic breast } \\
\text { implants with women seeking } \\
\text { other types of plastic surgery }\end{array}$ & 33.2 & $\begin{array}{l}\text { - White Caucasian } \\
\text { - Higher education } \\
\text { - Married } \\
\text { - Taller and thinner } \\
\text { - Younger age at first pregnancy or birth } \\
\text { - More often use of contraceptives }\end{array}$ \\
\hline $\begin{array}{l}\text { Fryzek et al. [36], (2000) } \\
\text { Cohort } \\
\text { Questionnaire data }\end{array}$ & $\begin{array}{l}\text { To determine the characteristics of } \\
\text { women with cosmetic breast } \\
\text { implants compared with breast } \\
\text { reduction patients and women in the } \\
\text { general population }\end{array}$ & 44 & $\begin{array}{l}\cdot \text { Smokers } \\
\text { - Taller and thinner } \\
\cdot \text { More pregnancies } \\
\text { - More likely to have experienced an early termination of pregnancy } \\
\cdot \text { Younger at first birth }\end{array}$ \\
\hline $\begin{array}{l}\text { Kjøller et al. [37], (2003) } \\
\text { Clinical follow up study } \\
\text { Questionnaire data }\end{array}$ & $\begin{array}{l}\text { To identify the characteristics of } \\
\text { women with cosmetic breast } \\
\text { implants compared with women } \\
\text { with other types of cosmetic surgery }\end{array}$ & 41 & $\begin{array}{l}\text { Smokers } \\
\text { - Thinner } \\
\text { - Younger age at menopause } \\
\text { - Greater number of full pregnancies } \\
\text { - More likely to have an induced abortion } \\
\text { - More likely to have used oral contraceptives } \\
\text { - More likely to have treatment for depression preoperatively }\end{array}$ \\
\hline $\begin{array}{l}\text { Breiting et al. [38], (2004) } \\
\text { Cohort } \\
\text { Questionnaire data }\end{array}$ & $\begin{array}{l}\text { To identify the characteristics of } \\
\text { women with cosmetic breast } \\
\text { implants compared with women with } \\
\text { breast reduction and women in } \\
\text { general population }\end{array}$ & 31 & $\begin{array}{l}\text { - Lower body mass index } \\
\text { - More full term pregnancies } \\
\text { - Younger at the time of first delivery } \\
\text { - More likely to use antidepressants, antianxiety, hypnotic drugs and } \\
\text { hormone replacement therapy }\end{array}$ \\
\hline $\begin{array}{l}\text { Lipworth et al. [39], (2009) } \\
\text { Cohort-epidemiologic follow up } \\
\text { Questionnaire data }\end{array}$ & $\begin{array}{l}\text { To identify the psychological } \\
\text { characteristics of women with } \\
\text { cosmetic breast implants }\end{array}$ & 32 & $\begin{array}{l}\text { - } 2 \text { times more likely to have sleeping disturbances after surgery } \\
\text { - More frequently reported having ever been treated for depression } \\
\text { but not apparent after implantation } \\
\text { - More likely to have prior the cosmetic surgery psychiatric hospital } \\
\text { admission }\end{array}$ \\
\hline $\begin{array}{l}\text { Nikolić et al. [40], (2013) } \\
\text { Prospective study } \\
\text { Questionnaire data }\end{array}$ & $\begin{array}{l}\text { Psychosocial characteristics and } \\
\text { motivational factors in woman } \\
\text { seeking cosmetic breast } \\
\text { augmentation surgery compared } \\
\text { with women who didn't have any } \\
\text { aesthetic operation before and didn't } \\
\text { want augmentation mammaplasty }\end{array}$ & 28.7 & $\begin{array}{l}\cdot \text { Thinner } \\
\cdot \text { Married } \\
\cdot \text { Higher education level }\end{array}$ \\
\hline
\end{tabular}

\section{DISCUSSION}

Women who have had cosmetic breast implants postoperatively report high overall satisfaction and experience good outcomes in psychological and psychosocial terms (Table 2) [23-32]. These benefits can be compromised due to postoperative com- 
plications such as infection, pain, hematoma, silicone implant hemorrhage, capsular contracture and loss of nipple sensation [41-49]. Complications and unreasonable expectations from the operation could contribute to affective disorders and impair the quality of life although this association has not been studied adequately [31].

According to the National Institute of Mental Health in the United States $[2,50]$ risk factors for suicide in general population are:

- Current ideation, intent, plan, access to means

- Previous suicide attempt or attempts

- Alcohol/Substance abuse

- Current or previous history of psychiatric diagnosis

- Impulsivity and poor self control

- Hopelessness-presence, duration, severity

- Recent losses-physical, financial, personal

- Recent discharge from an inpatient psychiatric unit

- Family history of suicide

- History of abuse (physical, sexual or emotional)

- Co-morbid health problems, a new diagnosis or worsening symptoms

- Age, gender, race (elderly or young adult, unmarried, white, male, lives alone)

- Same- sex sexual orientation

Pregnant women [51], having a child of less than 2-year-old [52] has been associated with lower suicidal risk. On the contrary, women of age range 35-44 years [53], unmarried, divorc- ed or single women without strong social support and occupational instability [53-56] have increased suicide risk. Miscarriage has also been linked to an increased maternal suicide risk especially when induced [57-60]. Less studied dimensions that might be related to suicide in the female population are: living in urban areas $[2,50,61]$ infertility $[62,63]$, the familial clustering of suicidal behaviors and chronic physical illness [64-66]. The overlapping characteristics among the general population and the female cosmetic breast implant patient that constitute predisposal factors for suicide according to this study are: alcohol consumption, history of psychiatric diagnosis and admission to psychiatric unit, relationship problems, patient's age, Caucasian race and reproductive history.

Silicone implants have been associated with the development of autoimmune diseases such as scleroderma, systematic erythematic lupus, mixed disorders of the connective tissue, rheumatoid arthritis and Sjögren's syndrome but this findings remain debatable [67-71]. More interestingly the implant explantation results in symptoms remission [72,73]. Less studied dimensions that could be related with the implant and it's potential contribution to suicide risk are the autoimmune syndrome induced by adjuvants (ASIA) and fibromyalgia syndrome (FMS) (Table 4). Maijers et al. [73] conducted a descriptive cohort study investigating 80 women with silicone breast implants and unexplained systemic symptoms (fatigue, arthralgia, myalgia and cognitive symptoms). Most women had pre-existent allergies and the majority of them (89\%) had silicone for cosmetic reasons. The median exposure time to the silicone implant was 14.5 years

\section{Table 4. Suicide risk factors}

\begin{tabular}{|c|c|c|}
\hline $\begin{array}{l}\text { Types of suicide risk } \\
\text { factors }\end{array}$ & Suicide risk factors in general population [50] & $\begin{array}{c}\text { Suicide risk factors that can be related with the cosmetic } \\
\text { breast augmentation patient }\end{array}$ \\
\hline $\begin{array}{l}\text { Psychological and } \\
\text { psychosocial factors }\end{array}$ & $\begin{array}{l}\text { Hopelessness-presence, duration, severity } \\
\text { Impulsivity and poor self control } \\
\text { Current ideation, intent, plan, access to means } \\
\text { Current or previous history of psychiatric diagnosis } \\
\text { Recent discharge from an inpatient psychiatric unit } \\
\text { Current or previous history of psychiatric diagnosis } \\
\text { Previous suicide attempt or attempts } \\
\text { Alcohol/Substance abuse } \\
\text { Family history of suicide }\end{array}$ & $\begin{array}{l}\text { Low self esteem-Body image }[26] \\
\text { Unrealistic expectations }[21,22,26] \\
\text { Depression, Anxiety, Neurotic personaliy [37-40] } \\
\text { Psychiatric unit admissions }[22,26] \\
\text { Alcohol consumption }[33-35,37,40]\end{array}$ \\
\hline $\begin{array}{l}\text { Demographic factors and } \\
\text { reproductive history }\end{array}$ & $\begin{array}{l}\text { Age, gender, race i.e., elderly or young adult, unmarried, } \\
\text { white, male, living alone } \\
\text { Recent losses-financial, personal } \\
\text { Same-sex sexual orientation }\end{array}$ & $\begin{array}{l}\text { Caucasian women of age range } 35-44 \text { years, unmarried, divorced or single } \\
\text { women }[33-35,37,53] \\
\text { Induced miscarriage }[34,36,37,57-60] \\
\text { Relationship problems [74] }\end{array}$ \\
\hline $\begin{array}{l}\text { Other factors i.e., stimuli that } \\
\text { can trigger stress response }\end{array}$ & $\begin{array}{l}\text { Co-morbid health problems, especially a newly diagnosed } \\
\text { problem or worsening symptoms } \\
\text { Recent losses-physical }\end{array}$ & $\begin{array}{l}\text { Augmentation mammaplasty operation/postoperative complications } \\
\text { [41-49,75,76] } \\
\text { Atopy-hyperimmune state in women with breast implantation-augmentation } \\
>10 \text { years }[73] \\
\text { Fibromyalgia syndrome (FMS) and low levels of } 5 \text {-hydroxyindoleacetic acid } \\
\text { (5-HIAA) in the Cerebrospinal fluid [77-84] } \\
\text { Autoimmune/Inflammatory Syndrome Induced by Adjuvants (ASIA) } \\
\text { [50,74-76,85] }\end{array}$ \\
\hline
\end{tabular}


and most women did not have any past medical history. The authors [73] resulted that all women had the typical clinical manifestations of ASIA (i.e., fatigue, night sweats, morning stiffness, joint and muscle pain, dermatological manifestations). Explantation of the implants was showed to reduce the symptoms. Maijers et al. [73], concluded that silicone breast implants may cause systemic symptoms in women with hyperimmune state or atopy. They suggested that this is line with intolerance to silicone. The authors highlighted that the probable association between the silicone breast implants and unexplained systemic symptoms should be taken seriously but acknowledged that strong associations between silicone implants and connective tissue diseases have not been demonstrated [73,86-90].

Furthermore silicone is often associated as one of the possible causes of FMS [91-93], an idiopathic, yet common chronic condition characterized by widespread musculoskeletal pain [93]. Stisi et al. [77], reviewed the literature in an attempt to determine pathoaetiological mechanisms of FMS and found, that patients with FMS have decreased levels of 5-Hydroxyindoleacetic acid (5-HIAA) a serotonin metabolite in the cerebrospinal fluid (CSF). This finding is significant because decreased levels of 5-HIAA in CSF has been identified as a possible suicide risk predictor in several independent studies [77-84].

In summary the current literature highlights the importance of preoperative psychiatric screening with particular interest in any previous psychiatric admissions and in current or previous mental disorders such as depression. The reason of the increased sui- cide risk among women with cosmetic breast augmentation remains unclear $[13,14]$ and further well designed epidemiological research is necessary.

Recently in the study of Overholser et al. [74] who investigated 148 individuals who died from suicide compared to adults who died from medical problems or accidents using psychological autopsy to assess Axis I psychiatric diagnosis concluded that a thorough evaluation of psychiatric diagnosis (i.e., depression), recent stressful life events (e.g., relationship, financial, work issues) and demographic characteristics are mandatory fields to be completed in every proper suicide risk assessment. These authors created a suicide risk model by conceptualizing the combination of demographic factors, psychiatric symptoms and recent stressful events highlighting the significance of the interactions between the variables. Moreover, they suggested that each demographic predictor on itself (e.g., unmarried, age) is not precise and results in false positive prediction errors. However they concluded that the identification of high suicide risk groups is not unrealistic and it can play an important role in the prevention of suicide if a holistic approach is taken into account especially with regards to stressful life events and precipitating factors. In the current literature addressing the issue of cosmetic breast augmentation and suicide, emphasis has been given to the importance of psychiatric history and demographic factors like independent variables associated with higher suicide risk.

Taking into account the recent studies of Overholser et al. [74], Maijers et al. [73], Stisi et al. [77], and from our systematic re-

\section{Fig. 1. Suicide risk model}

(A) Psychological and psychosocial factors i.e.,unrealistic expectations, mood disorders, low self esteem, body image, anxiety, depression, psychiatric unit admission, recent stressful life events, relationship problems, financial issues. (B) Demographic factors and reproductive history i.e., white, age, education, marital status, infertility, history of terminated pregnancies. (C) Stimuli that can trigger stress response i.e., augmentation mammaplasty operation/postoperative complications, atopy/ $>10$ years of implantation in cosmetic breast augmentation women/hyperimmune state, ASIA, FMS, and low levels of 5-HIAA in CSF. ASIA, autoimmune syndrome induced by adjuvants; FMS, fibromyalgia syndrome; 5-HIAA, 5-hydroxyindoleacetic acid; CSF, cerebrospinal fluid.

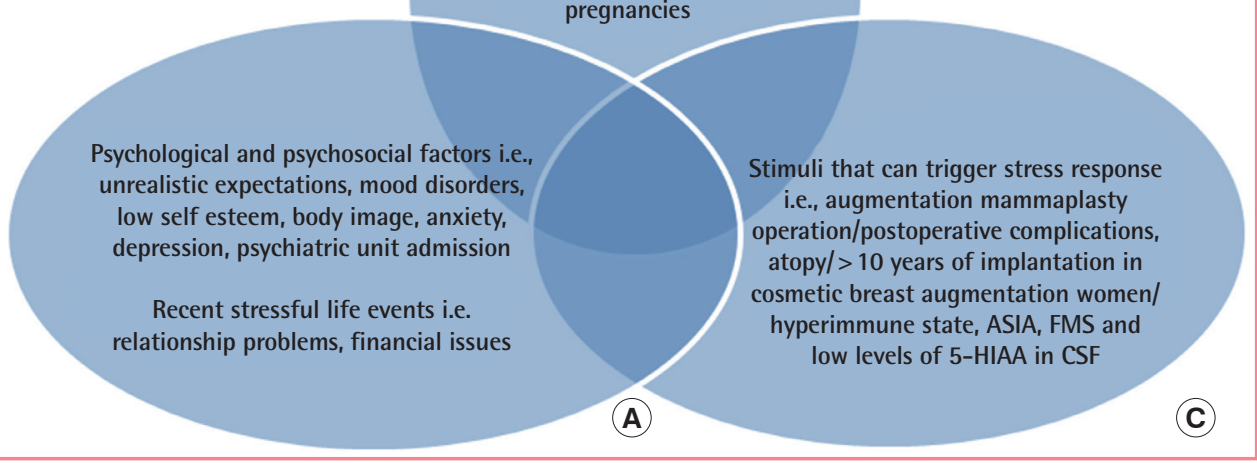


view (Tables 1-3), we have synthesized Fig. 1 below.

The above suicide risk model includes three interacting ellipses and each of them contains independent risk suicide variables. The model is specific for women seeking augmentation mammaplasty because it synthesizes the combination of suicide predictors in general population and incorporates the specific independent risk factors for suicide that are encountered in the cosmetic breast augmentation candidate (i.e., unrealistic expectations, postoperative complications). It includes the factors of atopy/hyperimmune state and low levels of 5-HIAA which is considered to be related with the development of ASIA syndrome and FMS respectively. Although it remains disputable, ASIA particularly in women with pre-existing allergies cannot be excluded from being an independent risk factor associated with the implant that can increase the risk of suicide in terms of being a stressful life event and a chronic physical illness, both risk factors for suicide $[2,50,74-76,85]$.

\section{CONCLUSIONS}

Suicide prediction is a complex task. A combination of demographic variables, psychiatric history, social, biological and other factors must be evaluated individually and in the context of the patient's whole environment. Women with underlying psychopathology, especially depression requiring previous hospital admission, medical history of terminated pregnancies should be considered high risk for suicide. Recent life stressors (financial, relationship or other personal issues) [74] that are not always part of a typical medical history might be important in predicting suicide risk and should be included in preoperative patient assessment. Breast augmentation surgery can stimulate a systematic stress response in several ways $[41-49,75,76]$ and increase the pre-existing risk of suicide in women who seek cosmetic mammaplasty. ASIA particularly in women with pre-existing allergies and FMS cannot be excluded from being independent risk factors. Each risk factor of suicide (i.e., unmarried, age, depression) has poor predictive value when considered independently and can result in false positive prediction errors. The suicide risk model we devise with interacting ellipses could be a helpful tool for plastic surgeons daily practice.

Our review concludes that there is 2 to 3 fold increased suicide risk among patients with augmentation mammaplasty. Although it remains unclear whether or not the augmentation mammaplasty operation can act as a trigger factor of suicide, it is more clear that women candidates have various degree of underlying psychopathology, demographic and psychosocial factors that are strongly related with increased suicide risk preoperatively. From this review no strong evidence that relates the augmentation mammaplasty operation itself with increased suicide risk occurs. ASIA and FMS syndrome despite being linked with systematic stress response which constitutes a suicide risk factor, do not cause increased suicide risk directly based on the existing evidence. It has not been excluded that factors such as: the operation itself, FMS, ASIA syndrome and > 10 years of implantation in women with hyperimmune state can affect the suicide risk of the mammaplasty patient postoperatively. However this requires further exploration. Our research concludes that there are overlapping risk factors to the breast augmentation candidate that can predispose to suicide (Table 4). The plastic surgeon needs to be aware of those factors and attempt to detect

\section{Table 5. Summarized risk factors}

\begin{tabular}{|c|c|}
\hline Types of suicide risk factors & $\begin{array}{c}\text { Suicide risk factors that can be related with the cosmetic breast augmentation patient/Suggested } \\
\text { guidelines and checklist for the augmentation mammaplasty patient }\end{array}$ \\
\hline Psychological and psychosocial factors & $\begin{array}{l}\text { 1. Low self-esteem-Body image }[26] \\
\text { 2. Unrealistic expectations }[21,22,26] \\
\text { 3. History or current symptoms of Depression, Anxiety or Neurotic personality [37-40] } \\
\text { 4. History of psychiatric unit admissions [22,26] } \\
\text { 5. The familial clustering of suicidal behaviors [64-66] } \\
\text { 6. Alcohol consumption }[33-35,37,40]\end{array}$ \\
\hline Demographic factors and reproductive history & $\begin{array}{l}\text { 7. Caucasian women } \\
\text { 8. Age range } 35-44 \text { years } \\
\text { 9. Unmarried, divorced or single women }[33-35,37,53] \\
\text { 10. Living in urban areas }[21,41] \\
\text { 11. Infertility }[32,42,70] \\
\text { 12. Induced miscarriage }[34,36,37,57-60] \\
\text { 13. Relationship problems } \\
\text { 14. Financial issues [74] }\end{array}$ \\
\hline $\begin{array}{l}\text { Postoperative factors i.e., stimuli that can } \\
\text { trigger stress response }\end{array}$ & $\begin{array}{l}\text { 15. Augmentation mammaplasty operation/postoperative complications }[41-49,75,76] \\
\text { 16. Atopy-hyperimmune state in women with breast implantation-augmentation }>10 \text { years }[73] \\
\text { 17. Fibromyalgia syndrome (FMS) and low levels of of } 5 \text {-hydroxyindoleacetic acid }(5-\mathrm{HIAA}) \text { in the Cerebrospinal fluid [77-84] } \\
\text { 18. Autoimmune/Inflammatory Syndrome Induced by Adjuvants (ASIA) }[50,74,76,85]\end{array}$ \\
\hline
\end{tabular}


them preoperatively and postoperatively. We created a pre and postoperative check list in an attempt to screen the mammaplasty patient in relation to suicide risk (Table 5).

It should be noted $10,2 \%$ of suicides do not have any of the suicide risk factors according to the study by Overholser et al. [74] This disconcerting observation should draw our attention to the fact that although doctors can always attempt to assess the risk for suicide they are unable to predict it with complete accuracy.

\section{REFERENCES}

1. National Institutes of Health. Statistics [Internet]. Rockville: National Institute of Mental Health; [cited 2014 Jul 28]. Available from: http://www.nimh.nih.gov/health/publications/ suicide-in-the-us-statistics-and-prevention/index.shtml\#risk.

2. Centers for Disease Control and Prevention. Injury prevention \& control: data \& statistics [Internet]. Atlanta: Centers for Disease Control and Prevention; 2014 [cited 2014 Jul 28]. Available from: http://www.cdc.gov/injury/wisqars/ index.html.

3. Brinton LA, Lubin JH, Burich MC, et al. Mortality among augmentation mammoplasty patients. Epidemiology 2001; 12:321-6.

4. Koot VC, Peeters PH, Granath F, et al. Total and cause specific mortality among Swedish women with cosmetic breast implants: prospective study. BMJ 2003;326:527-8.

5. Pukkala E, Kulmala I, Hovi SL, et al. Causes of death among Finnish women with cosmetic breast implants, 1971-2001. Ann Plast Surg 2003;51:339-42.

6. Jacobsen PH, Holmich LR, McLaughlin JK, et al. Mortality and suicide among Danish women with cosmetic breast implants. Arch Intern Med 2004;164:2450-5.

7. Brinton LA, Lubin JH, Murray MC, et al. Mortality rates among augmentation mammoplasty patients: an update. Epidemiology 2006;17:162-9.

8. Villeneuve PJ, Holowaty EJ, Brisson J, et al. Mortality among Canadian women with cosmetic breast implants. Am J Epidemiol 2006; 164:334-41.

9. Lipworth L, Nyren O, Ye W, et al. Excess mortality from suicide and other external causes of death among women with cosmetic breast implants. Ann Plast Surg 2007;59:119-23.

10. Morgan E. Suicide after breast augmentation. Epidemiology 2008;19:520-1.

11. Sher L. Cosmetic breast implants and suicide. Plast Reconstr Surg 2004;114:601-2.

12. McLaughlin JK, Lipworth L, Tarone RE. Suicide among women with cosmetic breast implants: a review of the epi- demiologic evidence. J Long Term Eff Med Implants 2003; 13:445-50.

13. Joiner TE Jr. Does breast augmentation confer risk of or protection from suicide? Aesthet Surg J 2003;23:370-5.

14. Crerand CE, Infield AL, Sarwer DB. Psychological considerations in cosmetic breast augmentation. Plast Surg Nurs 2009;29:49-57.

15. Sarwer DB, Brown GK, Evans DL. Cosmetic breast augmentation and suicide. Am J Psychiatry 2007;164:1006-13.

16. The Cochrane Collaboration [Internet]. Oxford : The Cochrane Collaboration; 2014 [cited 2014 Jul 28]. Available from: http://www.cochrane.org/cochrane-reviews.

17. PRISMA statement [Internet]. 2014 [cited 2014 Jul 28]. Available from: http://www.prisma-statement.org/statement.htm.

18. Oxman AD. Checklists for review articles. BMJ 1994;309: 648-51.

19. Littell JH, Corcoran J, Pillai VK. Systematic reviews and meta-analysis. Oxford: Oxford University Press; 2008.

20. Higgins JP, Green S, Cochrane Collaboration. Cochrane handbook for systematic reviews of interventions. Chichester: Wiley-Blackwell; 2008.

21. McLaughlin JK, Wise TN, Lipworth L. Increased risk of suicide among patients with breast implants: do the epidemiologic data support psychiatric consultation? Psychosomatics 2004;45:277-80.

22. Schlebusch L, Levin A. A psychological profile of women selected for augmentation mammaplasty. S Afr Med J 1983; 64:481-3.

23. Edgerton MT, Meyer E, Jacobson WE. Augmentation mammaplasty. II. Further surgical and psychiatric evaluation. Plast Reconstr Surg Transplant Bull 1961;27:279-302.

24. Shipley RH, O’Donnel JM, Bader KF. Psychosocial effects of cosmetic augmentation mammaplasty. Aesthetic Plast Surg 1978;2:429-34.

25. Sihm F, Jagd M, Pers M. Psychological assessment before and after augmentation mammaplasty. Scand J Plast Reconstr Surg 1978;12:295-8.

26. Beale S, Hambert G, Lisper HO, et al. Augmentation mammaplasty: the surgical and psychological effects of the operation and prediction of the result. Ann Plast Surg 1985;14: 473-93.

27. Kilmann PR, Sattler JI, Taylor J. The impact of augmentation mammaplasty: a follow-up study. Plast Reconstr Surg 1987; 80:374-8.

28. Meyer L, Ringberg A. Augmentation mammaplasty--psychiatric and psychosocial characteristics and outcome in a group of Swedish women. Scand J Plast Reconstr Surg Hand 
Surg 1987;21:199-208.

29. Young VL, NemecekJR, Nemecek DA. The efficacy of breast augmentation: breast size increase, patient satisfaction, and psychological effects. Plast Reconstr Surg 1994;94:958-69.

30. Rankin M, Borah GL, Perry AW, et al. Quality-of-life outcomes after cosmetic surgery. Plast Reconstr Surg 1998;102: 2139-45.

31. Cash TF, Duel LA, Perkins LL. Women's psychosocial outcomes of breast augmentation with silicone gel-filled implants: a 2-year prospective study. Plast Reconstr Surg 2002;109: 2112-21.

32. Sarwer DB, Infield AL, Baker JL, et al. Two-year results of a prospective, multi-site investigation of patient satisfaction and psychosocial status following cosmetic surgery. Aesthet Surg J 2008;28:245-50.

33. Schlebusch L. Negative bodily experience and prevalence of depression in patients who request augmentation mammoplasty. S Afr Med J 1989;75:323-6.

34. Cook LS, Daling JR, Voigt LF, et al. Characteristics of women with and without breast augmentation. JAMA 1997;277: 1612-7.

35. Brinton LA, Brown SL, Colton T, et al. Characteristics of a population of women with breast implants compared with women seeking other types of plastic surgery. Plast Reconstr Surg 2000; 105:919-27.

36. Fryzek JP, Weiderpass E, Signorello LB, et al. Characteristics of women with cosmetic breast augmentation surgery compared with breast reduction surgery patients and women in the general population of Sweden. Ann Plast Surg 2000;45: 349-56.

37. Kjoller K, Holmich LR, Fryzek JP, et al. Characteristics of women with cosmetic breast implants compared with women with other types of cosmetic surgery and population-based controls in Denmark. Ann Plast Surg 2003;50:6-12.

38. Breiting VB, Holmich LR, Brandt B, et al. Long-term health status of Danish women with silicone breast implants. Plast Reconstr Surg 2004;114:217-26.

39. Lipworth L, Kjoller K, Holmich LR, et al. Psychological characteristics of Danish women with cosmetic breast implants. Ann Plast Surg 2009;63:11-4.

40. Nikolic J, Janjic Z, Marinkovic M, et al. Psychosocial characteristics and motivational factors in woman seeking cosmetic breast augmentation surgery. Vojnosanit Pregl 2013;70: 940-6.

41. Bondurant S, Ernster VL, Herdman R, et al. Safety of silicone breast implants. Washington, D.C.: Institute of Medicine; 1999.

42. McGrath MH, Burkhardt BR. The safety and efficacy of breast implants for augmentation mammaplasty. Plast Reconstr Surg 1984;74:550-60.

43. Barton FF, Tebbetts JB. Augmentation mammaplasty. Sel Read Plast Surg 1989;5:1-26.

44. Brandt B, Breiting V, Christensen L, et al. Five years experience of breast augmentation using silicone gel prostheses with emphasis on capsule shrinkage. Scand J Plast Reconstr Surg 1984;18:311-6.

45. Winding O, Christensen L, Thomsen JL, et al. Silicon in human breast tissue surrounding silicone gel prostheses. A scanning electron microscopy and energy dispersive $\mathrm{X}$-ray investigation of normal, fibrocystic and peri-prosthetic breast tissue. Scand J Plast Reconstr Surg Hand Surg 1988;22:12730.

46. Rudolph R, Abraham J, Vecchione T, et al. Myofibroblasts and free silicon around breast implants. Plast Reconstr Surg 1978;62:185-96.

47. Argenta LC. Migration of silicone gel into breast parenchyma following mammary prosthesis rupture. Aesthetic Plast Surg 1983;7:253-4.

48. Eisenberg HV, Bartels RJ. Rupture of a silicone bag-gel breast implant by closed compression capsulotomy: case report. Plast Reconstr Surg 1977;59:849-50.

49. Huang TT, Blackwell SJ, Lewis SR. Migration of silicone gel after the "squeeze technique" to rupture a contracted breast capsule. Case report. Plast Reconstr Surg 1978;61:277-80.

50. National Institute of Mental Health. Suicide in America: frequently asked questions [Internet]. Rockville: National Institute of Mental Health; [cited 2014 Jul 28]. Available from: http://www.nimh.nih.gov/health/publications/suicide-inamerica/index.shtml.

51. Hawton K, Harriss L. The changing gender ratio in occurrence of deliberate self-harm across the lifecycle. Crisis 2008; 29:4-10.

52. Qin P, Agerbo E, Westergard-Nielsen N, et al. Gender differences in risk factors for suicide in Denmark. Br J Psychiatry 2000;177:546-50.

53. White A, Holmes M. Patterns of mortality across 44 countries among men and women aged $15-44$ years. J Mens Health 2006;3:139-51.

54. Palladino CL, Singh V, Campbell J, et al. Homicide and suicide during the perinatal period: findings from the National Violent Death Reporting System. Obstet Gynecol 2011;118: 1056-63.

55. Samandari G, Martin SL, Kupper LL, et al. Are pregnant and postpartum women: at increased risk for violent death? Suicide and homicide findings from North Carolina. Matern Child Health J 2011;15:660-9. 
56. Murray D, Cox JL, Chapman G, et al. Childbirth: life event or start of a long-term difficulty? Further data from the Stokeon-Trent controlled study of postnatal depression. Br J Psychiatry 1995;166:595-600.

57. Gissler M, Hemminki E, Lonnqvist J. Suicides after pregnancy in Finland, 1987-94: register linkage study. BMJ 1996;313: 1431-4.

58. Gissler M, Berg C, Bouvier-Colle MH, et al. Injury deaths, suicides and homicides associated with pregnancy, Finland 1987-2000. Eur J Public Health 2005;15:459-63.

59. Steinberg JR, Becker D, Henderson JT. Does the outcome of a first pregnancy predict depression, suicidal ideation, or lower self-esteem? Data from the National Comorbidity Survey. Am J Orthopsychiatry 2011;81:193-201.

60. Morgan CL, Evans M, Peters JR. Suicides after pregnancy. Mental health may deteriorate as a direct effect of induced abortion. BMJ 1997;314:902.

61. Thorslund J. Ungdomsselvmord og moderniseringsproblemer blandt Inuit i Grønland [dissertation]. Holte: SocPol; 1992.

62. Kjaer TK, Jensen A, Dalton SO, et al. Suicide in Danish women evaluated for fertility problems. Hum Reprod 2011;26: 2401-7.

63. da Silva RA, da Costa Ores L, Jansen K, et al. Suicidality and associated factors in pregnant women in Brazil. Community Ment Health J 2012;48:392-5.

64. Brent DA, Perper JA, Moritz G, et al. Familial risk factors for adolescent suicide: a case-control study. Acta Psychiatr Scand 1994;89:52-8.

65. Murphy GE, Wetzel RD. Family history of suicidal behavior among suicide attempters. J Nerv Ment Dis 1982;170:86-90.

66. Gould MS, Fisher P, Parides M, et al. Psychosocial risk factors of child and adolescent completed suicide. Arch Gen Psychiatry 1996;53:1155-62.

67. Sahn EE, Garen PD, Silver RM, et al. Scleroderma following augmentation mammoplasty. Report of a case and review of the literature. Arch Dermatol 1990;126:1198-202.

68. Spiera H. Scleroderma after silicone augmentation mammoplasty.JAMA 1988;260:236-8.

69. Schumann D. Health risks for women with breast implants. Nurse Pract 1994;19:19-20, 3-5, 9-30.

70. Brozena SJ, Fenske NA, Cruse CW, et al. Human adjuvant disease following augmentation mammoplasty. Arch Dermatol 1988;124:1383-6.

71. Kumagai Y, Shiokawa Y, Medsger TA Jr, et al. Clinical spectrum of connective tissue disease after cosmetic surgery. Observations on eighteen patients and a review of the Japanese literature. Arthritis Rheum 1984;27:1-12.
72. Oberle K, Allen M. Breast augmentation surgery: a women's health issue. J Adv Nurs 1994;20:844-52.

73. Maijers MC, de Blok CJ, Niessen FB, et al. Women with silicone breast implants and unexplained systemic symptoms: a descriptive cohort study. Neth J Med 2013;71:534-40.

74. Overholser JC, Braden A, Dieter L. Understanding suicide risk: identification of high-risk groups during high-risk times. J Clin Psychol 2012;68:349-61.

75. Implants; IoMUCotSoSB, Bondurant S, Ernster V, et al. Safety of silicone breast implants. Washington (DC): The National Academies Press; 1999.

76. Immunology of silicone [Internet]. Washington (DC): National Academies Press (US); 1999 [cited 2014 Jul 28]. Available from: http://www.ncbi.nlm.nih.gov/books/NBK44795/.

77. Stisi S, Cazzola M, Buskila D, et al. Etiopathogenetic mechanisms of fibromyalgia syndrome. Reumatismo 2008;60 Suppl 1:25-35.

78. Russell IJ, Vaeroy H, Javors M, et al. Cerebrospinal fluid biogenic amine metabolites in fibromyalgia/fibrositis syndrome and rheumatoid arthritis. Arthritis Rheum 1992;35:550-6.

79. Engstrom G, Alling C, Blennow K, et al. Reduced cerebrospinal HVA concentrations and HVA/5-HIAA ratios in suicide attempters. Monoamine metabolites in 120 suicide attempters and 47 controls. Eur Neuropsychopharmacol 1999; 9:399-405.

80. Nordstrom P, Samuelsson M, Asberg M, et al. CSF 5-HIAA predicts suicide risk after attempted suicide. Suicide Life Threat Behav 1994;24:1-9.

81. Roy A, De Jong J, Linnoila M. Cerebrospinal fluid monoamine metabolites and suicidal behavior in depressed patients. A 5-year follow-up study. Arch Gen Psychiatry 1989; 46:609-12.

82. Asberg M, Traskman L, Thoren P. 5-HIAA in the cerebrospinal fluid. A biochemical suicide predictor? Arch Gen Psychiatry 1976;33:1193-7.

83. Lidberg L, Tuck JR, Asberg M, et al. Homicide, suicide and CSF 5-HIAA. Acta Psychiatr Scand 1985;71:230-6.

84. Arango V, Huang YY, Underwood MD, et al. Genetics of the serotonergic system in suicidal behavior.J Psychiatr Res 2003; 37:375-86.

85. Wilson KG, Kowal J, Henderson PR, et al. Chronic pain and the interpersonal theory of suicide. Rehabil Psychol 2013; 58:111-5.

86. Sher L. Cosmetic breast implants and suicide. Plast Reconstr Surg 2004;114:601-2.

87. Holmich LR, Lipworth L, McLaughlin JK, et al. Breast implant rupture and connective tissue disease: a review of the literature. Plast Reconstr Surg 2007;120:62S-69S. 
88. Janowsky EC, Kupper LL, Hulka BS. Meta-analyses of the relation between silicone breast implants and the risk of connective-tissue diseases. N Engl J Med 2000;342:781-90.

89. Hajdu SD, Agmon-Levin N, Shoenfeld Y. Silicone and autoimmunity. Eur J Clin Invest 2011;41:203-11.

90. Caldeira M, Ferreira AC. Siliconosis: autoimmune/inflammatory syndrome induced by adjuvants (ASIA). Isr Med Assoc J 2012;14:137-8.
91. McBeth J, Silman AJ. The role of psychiatric disorders in fibromyalgia. Curr Rheumatol Rep 2001;3:157-64.

92. Bell IR, Baldwin CM, Schwartz GE. Illness from low levels of environmental chemicals: relevance to chronic fatigue syndrome and fibromyalgia. Am J Med 1998;105:74S-82S.

93. Richards S, Cleare AJ. Fibromyalgia: biological correlates. Curr Opin Psychiatry 2000;13:623-8. 